\title{
Can sensitivity to temperature during germination help predict global warming vulnerability?
}

\author{
Anne Cochrane* \\ Department of Parks and Wildlife, Locked Bag 104, Bentley Delivery Centre, Western Australia 6983, Australia
}

(Received 9 June 2015; accepted after revision 5 November 2015; first published online 22 December 2015)

\begin{abstract}
Seed germination is vital for persistence in species that rely on seeds for post-disturbance regeneration. It is a high-risk phase and vulnerable to environmental parameters. Here, I assessed temperature sensitivity for germination in Banksia L.f. (Proteaceae) from south-western Australia, screening all 38 endemic obligate seeder species. A bi-directional temperature gradient plate with 49 temperature combinations (constant and fluctuating) between 5 and $40^{\circ} \mathrm{C}$ was used to profile germination temperature requirements and identify upper and lower temperature thresholds for germination. Using these data the impact of increasing temperatures on germination in these species was modelled under high and low greenhouse gas scenarios for 2050 and 2070. The results suggest that many Banksia species from the region have wide physiological tolerance for high germination temperatures, although a number of common, but geographically restricted species, such as $B$. praemorsa, $B$. oreophila and $B$. quercifolia, have more narrow temperature windows for germination than at least one of the rarer species (B. verticillata). Only $B$. dryandroides is expected to decline in germination in the future; however, the optimal germination timing for many species is predicted to occur later under climate warming. In conjunction with declining rainfall, this germination delay will place seedlings closer to the summer dry in this seasonal Mediterranean-climate ecosystem and thus they will be more vulnerable to desiccation. The framework developed here can be used to identify vulnerable species for monitoring of early population decline.
\end{abstract}

Keywords: climate change, regeneration, seed germination, temperature constraints

*Correspondence

Email: anne.cochrane@dpaw.wa.gov.au

\section{Introduction}

Small environmental changes during critical phases in a plant's life cycle can alter optimal timing for lifehistory transitions; these changes can have profound effects on plant distribution and survival by impacting on the reproductive success of individuals (Lloret et al., 2004; Gworek et al., 2006). The high-risk, transitional germination stage of the life cycle that takes a seed to a seedling is of major importance for population persistence (Harper, 1977; Silvertown and Charlesworth, 2001), in particular for obligate seeder species (i.e. those killed by fire). In fire-prone habitats this stage is often linked to the occurrence of fire (Bradstock, 1991; Whelan, 1995).

Strong scientific evidence indicates that the environment is changing, and with these changes comes the potential for negative consequences for global biodiversity (IPPC, 2013). It appears certain that the Mediterranean-climate heathland systems of the South West Australian Floristic Region (SWAFR) sensu Hopper and Gioia (2004) will suffer a significant loss of plant diversity by the end of this century due to environmental change (www.environment.gov.au/ climate-change; Malcolm et al., 2006; Fitzpatrick et al., 2008; Yates et al., 2010). Already, these ecosystems are under stress from a history of vegetation fragmentation, changed hydrology and introduced diseases. Species distribution models are predicting high rates of extinction for the endemic species of this megadiverse region, based on reduced rainfall (Fitzpatrick et al., 2008), rising temperatures (Pouliquen-Young and Newman, 2000) and a doubling of carbon dioxide concentrations (Malcolm et al., 2006). Long-lived, obligate-seeding species with limited dispersal ability and those that are already at the limits of their geographic range may be highly sensitive to changes in the environment (Hughes et al., 1996; McCarthy, 2001; Parmesan and Yohe, 2003). Seeds and seedlings are expected to be particularly sensitive to climate variability and directional climate change (Hovenden et al., 2008; Ooi et al., 2009; Ooi, 2012; Cochrane et al., 2014a), but sensitivity will depend on species' genetic 
and phenotypic plasticity, life-history characteristics, and ecological niche and geographic distribution (Broadhurst et al., 2006; Nicotra et al., 2010).

In the SWAFR, temperature and precipitation gradients are strongly influenced by latitude in the relatively low-relief landscape of the region, and are highly correlated. Average annual rainfall declines and temperature increases in northward and eastward directions, as a result of the winter rainfall systems. The region, which is located at the cool, wet end of a hot, dry continent, has already experienced changes in temperature and precipitation. Observed temperatures for all of Western Australia have increased by approximately $0.8^{\circ} \mathrm{C}$ since 1910 , with most of the increase occurring since 1950 (www.bom.gov.au; www.ioci. org.au). Total annual rainfall in the SWAFR itself has declined over the past 50 years and has been most apparent in later autumn and early winter (Bates et al., 2012). Future climate change scenarios vary but there are some common themes: there will be a continued upward change in mean annual temperature and a downward trend in patterns of precipitation. The coolest and wettest climate zones of the south-west will contract (Bates et al., 2008, 2012) with a $0.5-2^{\circ} \mathrm{C}$ temperature increase and a $2-20 \%$ rainfall reduction projected for the region by 2030. Species confined to the more southerly areas of the region will, by definition, be at great risk, with nowhere to go. Changes in species distributions are predicted. For example, Fitzpatrick et al. (2008) forecast that $66 \%$ of the 100 species of Banksia (Proteaceae) they investigated would suffer declines in geographic range by 2080 , based on simulated migration, with $5-25 \%$ of species predicted to become extinct. Similar range collapses were reported by Yates et al. (2010) when they combined the effects of climate change with land transformation to increase the predictive ability of the models for the future of SWAFR Banksia species. Although modelling climate scenarios, land transformation and simulating migration are useful tools, models only provide hypotheses and are limited by the complexity of demographic processes in natural systems (e.g. see Pearson and Dawson, 2003). Such models typically assume that current species distributions are driven primarily by existing climates. However, the physiological thresholds for reproduction, growth and survival for many species are generally unknown and quantitative data on plant performance and climate tolerances are urgently required.

One of the most critical seed-related issues requiring investigation is how environmental variables that drive population performance will affect life-cycle events such as germination (Cochrane et al., 2015). Temperature is one driver that plays a critical role in the regulation of seed germination (Probert, 2000). Consequently, understanding temperature requirements for germination will help alert us to likely changes to species persistence under altered climates (Cochrane et al., 2011, 2014b). The disruption of current germination strategies as a consequence of changes in temperature associated with predicted climate change is likely to result in alteration of demographic rates, potential mismatch in the timing and placement of germination for many species and, ultimately, changes in geographic distribution (Luna et al., 2012; Mondoni et al., 2012; Ooi, 2012). Obligateseeding species that are killed by fire and rely solely on seeds for regeneration should make good 'indicator species' for tracking the impact of warming climates on germination traits.

Here, germination temperature profiles developed for both common and widespread obligate-seeder species in the genus Banksia L.f. (Banksia subg. Banksia sensu George) endemic to the cool, wet South Western Australian Botanical Province (SWAFR) are reported. The impact of altered temperatures associated with anthropogenic climate change on future germination response under forecast future climates are modelled. Two climate severity scenarios (low and high radiative forcing) for two time periods (2050 and 2070) were chosen for simulation. Two hypotheses were explored: (1) that increasing temperatures relevant to the climate scenarios would alter germination traits such as percentage and timing; and (2) that species with more restricted distributions (reflected in their listing as conservation-dependent species) would be affected disproportionately by these temperature changes.

\section{Materials and methods}

\section{Study species and seed collection}

In Western Australia, Banksia is a genus represented by 158 species, almost all endemic to the SWAFR (http:/ / florabase.dpaw.wa.gov.au/statistics / WACensus 2013-06-01_table3.pdf). Originally comprised of 73 species (George, 1999), the genus underwent a taxonomic rearrangement to include Dryandra R.Br. (Mast and Thiele, 2007). Ninety-three taxa are listed as conservation-dependant (http://florabase.dpaw.wa. gov.au/). The genus is generally confined to the cooler south-western end of Western Australia by climate, being naturally restricted to areas with a $>250 \mathrm{~mm}$ rainfall isohyet (Lamont and Connell, 1996). In the winter-wet, summer-dry Mediterranean-type climate of the SWAFR, germination of Banksia seeds occurs in response to the cool, wet conditions prevalent in late autumn and winter. Banksias hold their fruits in the canopy of the plant in woody cones (serotiny) with seed dispersal triggered by the heat-induced opening of cones (Lamont et al., 1991). The degree of serotiny can vary among species and along climatic gradients (Cowling and Lamont, 1985), but for most of the 
obligate-seeder species, recruitment is limited to the post-fire phase, with some exceptions. These nonlignotuberous obligate seeders are considered to be most vulnerable to stressors such as altered climatic conditions and too frequent fire (Lamont et al., 2007), with sprouters potentially having wider environmental tolerances and greater persistence once mature (Bond and Midgley, 2001). In the fire-prone vegetation communities of the SWAFR some $60 \%$ of Banksia species (Banksia subg. Banksia sensu George) are obligate seeders (Lamont and Markey, 1995).

Fruiting cones were collected from the wild from populations of all 38 of the obligate-seeder Banksia species (including three sprouter species) from the SWAFR, between July 2008 and June 2009 (47 collections) (Fig. 1, see Table 1). Six species with restricted geographic distribution and of conservation concern were included in the experiment (see Table 1). Cones were sampled from a minimum of 20 individuals within each population and generally from the most recent cohort of mature fruit. Fruiting cones of Banksia consist of few to many hard, woody follicles containing two valves that split open to release one or two seeds and an intervening plate known as the septum. The non-endospermic seeds have a membranous terminal wing for wind dispersal.

Seeds were extracted from woody cones using a gas flame from a blowtorch until the follicles cracked open $(2-4 \mathrm{~s})$, then cones were soaked in water for $6 \mathrm{~h}$ before being placed to dry in a warm location. Under these conditions, the time taken for seeds to extract from fruiting cones varied between species, ranging from immediately after burning to the requirement for a week of drying. After extraction, seeds were stored in a drying room at $15^{\circ} \mathrm{C}$ and $15 \%$ relative humidity $(\mathrm{RH})$ until use. Seedlots were allowed to equilibrate to ambient laboratory conditions $\left(\right.$ c. $\left.20^{\circ} \mathrm{C} / 50 \% \mathrm{RH}\right)$ prior to incubation on agar. Once released from woody fruiting cones, Banksia seeds are highly viable, show no innate dormancy and germinate freely when given sufficient moisture and an appropriate temperature. Herbarium voucher specimens were made at the time of fruit collection to vouch for the identity of the species, and were subsequently lodged with the Western Australian Herbarium, Perth, Australia (http://florabase.dpaw.wa.gov.au/).

\section{Environmental data}

Climate data (average monthly minimum and maximum temperatures and average monthly precipitation) for each seed source site were obtained from WorldClim, a set of global climate layers with a spatial resolution of approximately $1 \mathrm{~km}^{2}$ (Hijmans et al., 2005). The data for 'current' conditions were derived from 1950-2000 averages. Future projections for the same climate variables were downloaded from the downscaled Hadley Centre Global Environment Model version 2 (HADGEM2-ES http://www.metoffice.gov. $\mathrm{uk} / \mathrm{research} /$ modelling-systems/unified-model/ climate-models/hadgem2) using low [Representative Concentration Pathway (RCP) 2.6] and high (RCP 8.5) greenhouse gas emission scenarios for two time periods (2050 and 2070). The HADGEM2-ES model (Jones et al., 2011) was chosen because it includes dynamic vegetation, ocean biology and atmospheric chemistry, it was used in the Fifth Assessment Report of the Intergovernmental Panel on Climate Change (IPPC, 2013) and has previously been used in simulating germination response in native species (FernándezPascual et al., 2015).

\section{Experimental design}

A bi-directional temperature gradient plate (TGP) (Model GRD1, Grant Instruments, Cambridge, UK) was used to provide 196 different temperature combinations that provided both constant and diurnally alternating temperatures ranging from approximately 5 to $40^{\circ} \mathrm{C}$. A 12 -h thermoperiod was used. When the TGP gradient ran in bi-directional mode, one-half of the cell grids received $12 \mathrm{~h}$ of light during the warm part of the diurnal cycle and the other half received $12 \mathrm{~h}$ of light during the cool part of the cycle. Four species were germinated at each run of the TGP, providing 49 temperature combinations per species with temperature amplitudes between 0 and $23^{\circ} \mathrm{C}$. For each temperature combination either 5 or 10 seeds were used, depending on seed size. Because of space constraints on the TGP, no replication of temperature combinations was possible. Seeds, without wings, were sown on the surface of $1 \% \mathrm{w} / \mathrm{v}$ water-agar on 35-mm Petri dishes. Actual temperatures experienced by seeds were determined by five thermistors on the plate, connected to a data logger (Grant Instruments Squirrel 2020 Series, Cambridge, UK). All environments received irradiance for $12 \mathrm{~h} \mathrm{~d}^{-1}$ (fluorescent white light $\sim 50 \mu \mathrm{mol} \mathrm{m}^{-2} \mathrm{~s}^{-1}$ ). Germination was scored every $2-3 \mathrm{~d}$ and was defined as visible radicle emergence. Each germination test ran for 6 weeks, at which time remaining seeds were subjected to a cut-test to determine viability. Percentage germination was calculated as the percentage of seeds that germinated within the incubation period. Seeds with a hard, white endosperm and embryo were scored as potentially viable; empty seeds were removed from the original count.

\section{Data analysis}

To determine the response curves for each species and identify the optimal average and diurnally alternating temperature conditions for germination 


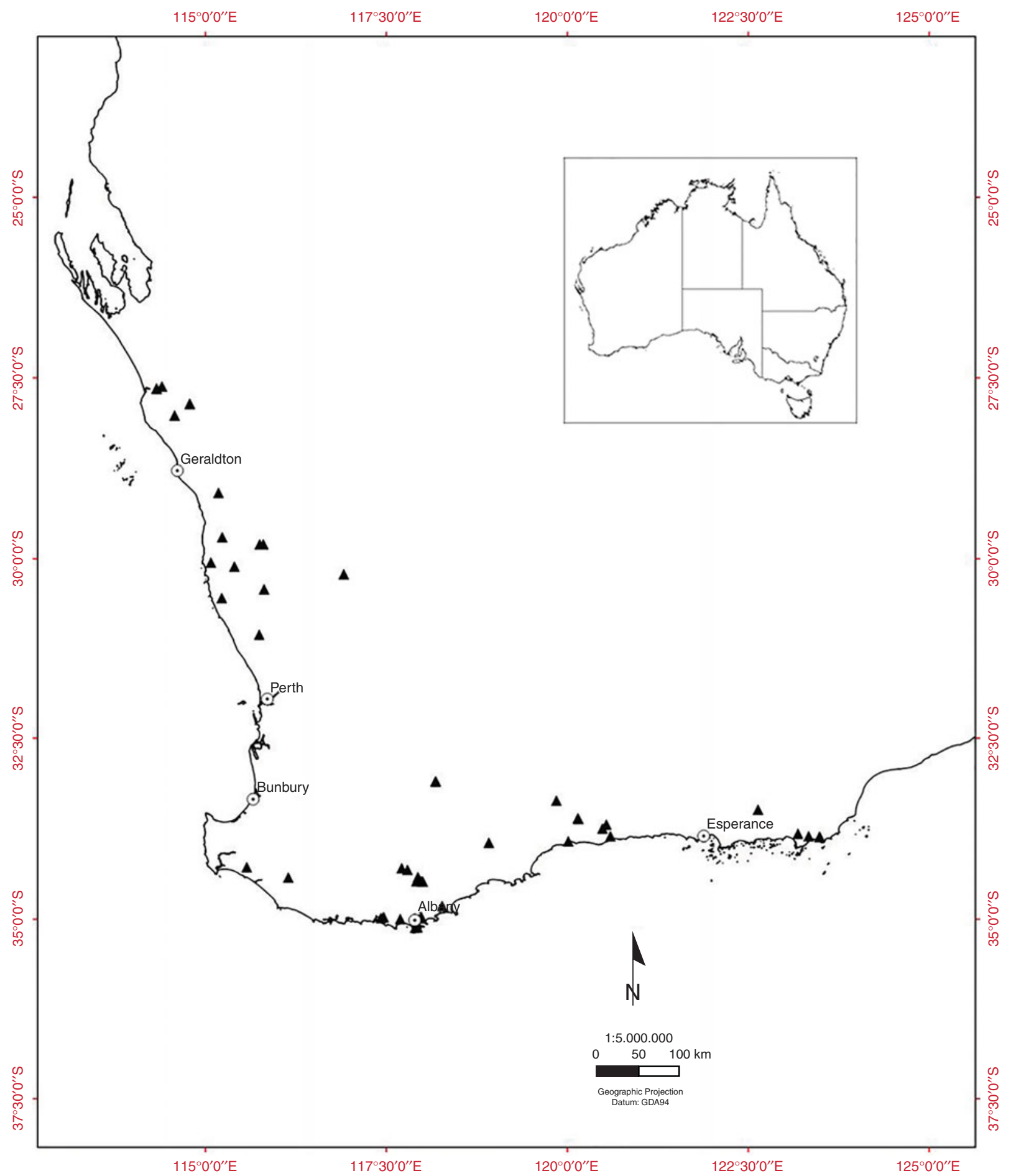

Figure 1. The location of 47 Banksia seed source sites $(\boldsymbol{\Delta})$ in the South Western Australian Floristic Region.

(for both percentage germination and mean time to germination), regression models were fitted to the data from the TGP experiment. The proportion of seeds that germinated per dish and mean time to germination were the dependent variables in logistic and ordinary linear regression models, respectively. Each seed was treated as an independent unit in the logistic regression (i.e. each seed could either germinate or not during the experiment). Mean time to germination (MTG) was calculated for all temperatures (where germination occurred) using the equation:

$$
\mathrm{MTG}=\sum(n \times d) / N
$$

where $n=$ number of seeds germinated between scoring intervals; $d=$ the incubation period in days at 
Table 1. Mean time to germination and the average and amplitude of temperature fluctuations at maximum germination for 41 Banksia species (47 collections) from Western Australia. All species are endemic to the SWARF and are killed by fire (obligate seeders) unless indicated by \# (resprouters)

\begin{tabular}{|c|c|c|c|c|c|c|c|c|c|c|}
\hline \multirow[b]{2}{*}{ Species } & \multicolumn{4}{|c|}{ Temperature ${ }^{\circ} \mathrm{C}$} & \multirow{2}{*}{$\begin{array}{l}\text { Mean time to } \\
\text { germination } \\
\text { (MTG) days }\end{array}$} & \multirow{2}{*}{$\begin{array}{c}\text { Maximum } \\
\text { germination } \\
(\%)\end{array}$} & \multirow[b]{2}{*}{ Latitude } & \multirow[b]{2}{*}{ Longitude } & \multirow[b]{2}{*}{ Distribution } & \multirow[b]{2}{*}{ Location } \\
\hline & Day & Night & Amplitude & Mean & & & & & & \\
\hline Banksia aculeata & 18.6 & 5.1 & 14.5 & 12.4 & 17.6 & 100 & 34.32 & 117.79 & $\mathrm{~S}^{*}$ & Stirling Range \\
\hline \multirow[t]{2}{*}{ Banksia ashbyii } & 14.7 & 17.1 & 2.4 & 15.9 & 13.9 & 100 & 27.86 & 114.78 & $\mathrm{~N}$ & Kalbarri \\
\hline & 23.4 & 12.7 & 10.7 & 18.0 & 13.9 & 100 & & & & \\
\hline Banksia attenuata \# & 20.6 & 16.6 & 4 & 18.6 & 10.0 & 100 & 29.80 & 115.75 & W & Carnamah $(\mathrm{C})$ \\
\hline Banksia attenuata \# & 15.2 & 25 & 9.8 & 20.1 & 10.4 & 100 & 27.65 & 114.33 & $\mathrm{~W}$ & Kalbarri (K) \\
\hline Banksia baxteri & 6.9 & 16.7 & 9.8 & 11.8 & 14.0 & 100 & 34.48 & 118.00 & S & Stirling Range \\
\hline Banksia baueri & 15.9 & 19.3 & 3.4 & 17.6 & 14.3 & 100 & 34.47 & 118.18 & $\mathrm{~S}$ & Stirling Range (SRNP) \\
\hline Banksia baueri & 15.9 & 16.6 & 0.7 & 16.2 & 12.9 & 100 & 33.09 & 117.99 & S & Tarin Rock (TR) \\
\hline Banksia baueri & 13.1 & 16.6 & 3.5 & 14.8 & 15.4 & 100 & 33.92 & 120.01 & $S$ & East Mt Barren (EMB) \\
\hline Banksia benthamiana & 22.4 & 7.7 & 14.7 & 15.1 & 16.6 & 100 & 30.21 & 116.91 & $\mathrm{~N}$ & Dalwallinu \\
\hline Banksia blechnifolia & 15.8 & 16.5 & 0.6 & 16.1 & 18.4 & 100 & 33.36 & 119.85 & $\mathrm{~S}$ & Ravensthorpe \\
\hline Banksia brownii & 13.2 & 16.5 & 3.3 & 14.8 & 14.8 & 90 & 35.06 & 117.92 & $S^{*}$ & Albany \\
\hline Banksia burdettii & 21.2 & 17.1 & 4.1 & 19.2 & 21.0 & 100 & 30.42 & 115.81 & $\mathrm{~N}$ & Badgingarra \\
\hline \multirow[t]{2}{*}{ Banksia caleyi } & 9.7 & 19.4 & 9.7 & 14.6 & 16.2 & 100 & 34.47 & 117.92 & $S$ & Stirling Range \\
\hline & 15.4 & 8.5 & 6.9 & 12.0 & 16.2 & 100 & & & & \\
\hline Banksia coccinea & 18.6 & 14.3 & 4.3 & 16.5 & 26.7 & 89 & 34.99 & 117.99 & $\mathrm{~S}$ & Albany \\
\hline Banksia dryandroides & 6.8 & 14 & 7.1 & 10.4 & 21.3 & 100 & 34.82 & 118.27 & $\mathrm{~S}$ & Wellstead \\
\hline Banksia grandis \# & 21.0 & 5.8 & 15.2 & 13.4 & 11.4 & 100 & 35.00 & 117.69 & $\mathrm{~W}$ & Albany \\
\hline \multirow[t]{2}{*}{ Banksia hookeriana } & 6.2 & 26.2 & 20 & 16.2 & 9.0 & 100 & 29.70 & 115.23 & $\mathrm{~N}$ & Eneabba \\
\hline & 12 & 26.2 & 14.2 & 19.1 & 9.0 & 100 & & & & \\
\hline Banksia laevigata & 13.1 & 13.8 & 0.7 & 13.4 & 20.1 & 100 & 33.60 & 120.15 & S & Ravensthorpe \\
\hline Banksia lanata & 23.1 & 11 & 12.1 & 17.1 & 9.8 & 100 & 30.11 & 115.40 & $\mathrm{~N}$ & Badgingarra \\
\hline Banksia laricina & 9.1 & 26.2 & 17.1 & 17.7 & 15.4 & 100 & 31.06 & 115.74 & $\mathrm{~N}$ & Moore River \\
\hline Banksia lehmanniana & 12.3 & 18.0 & 5.7 & 15.1 & 17.4 & 100 & 33.61 & 120.15 & $\mathrm{~S}$ & Ravensthorpe \\
\hline Banksia leptophylla & 25.2 & 7.7 & 17.5 & 16.5 & 8.0 & 100 & 30.05 & 115.08 & $\mathrm{~N}$ & Coorow \\
\hline Banksia lindleyana & 20.7 & 23.2 & 2.5 & 21.9 & 11.6 & 100 & 28.02 & 114.57 & $\mathrm{~N}$ & Kalbarri \\
\hline Banksia meisneri subsp. ascendens & 9.9 & 13.7 & 3.8 & 11.8 & 19.7 & 100 & 34.28 & 115.57 & $\mathrm{~S}^{*}$ & Augusta \\
\hline \multirow[t]{4}{*}{ Banksia media } & 13.9 & 18.9 & 5.0 & 16.4 & 12.6 & 100 & 33.86 & 123.48 & $\mathrm{~S}$ & Esperance \\
\hline & 19.3 & 18.9 & 0.4 & 19.1 & 12.6 & 100 & & & & \\
\hline & 24.5 & 7.6 & 17.0 & 16.1 & 12.6 & 100 & & & & \\
\hline & 24.5 & 13.2 & 11.3 & 18.9 & 12.6 & 100 & & & & \\
\hline Banksia nutans & 19.3 & 16.1 & 3.2 & 17.7 & 13.0 & 100 & 33.82 & 123.19 & $\mathrm{~S}$ & Esperance \\
\hline Banksia occidentalis & 13.2 & 22.6 & 9.4 & 17.9 & 19.1 & 100 & 34.97 & 117.46 & $\mathrm{~S}$ & Denmark \\
\hline Banksia oreophila & 9.9 & 12.8 & 2.9 & 11.4 & 22.1 & 100 & 34.29 & 117.71 & $\mathrm{~S}$ & Stirling Range \\
\hline
\end{tabular}


Table 1. Continued

\begin{tabular}{|c|c|c|c|c|c|c|c|c|c|c|}
\hline \multirow[b]{2}{*}{ Species } & \multicolumn{4}{|c|}{ Temperature ${ }^{\circ} \mathrm{C}$} & \multirow{2}{*}{$\begin{array}{l}\text { Mean time to } \\
\text { germination } \\
\text { (MTG) days }\end{array}$} & \multirow{2}{*}{$\begin{array}{l}\text { Maximum } \\
\text { germination } \\
(\%)\end{array}$} & \multirow[b]{2}{*}{ Latitude } & \multirow[b]{2}{*}{ Longitude } & \multirow[b]{2}{*}{ Distribution } & \multirow[b]{2}{*}{ Location } \\
\hline & Day & Night & Amplitude & Mean & & & & & & \\
\hline Banksia petiolaris & 21.0 & 8.1 & 12.9 & 14.5 & 17.4 & 100 & 33.69 & 120.54 & $S$ & Munglinup \\
\hline \multirow{2}{*}{ Banksia pilostylis } & 8.1 & 21.7 & 13.6 & 14.9 & 14.6 & 100 & 33.85 & 120.60 & S & Munglinup (M) \\
\hline & 19.0 & 16.2 & 2.7 & 17.6 & 14.6 & 100 & & & & \\
\hline \multirow[t]{2}{*}{ Banksia pilostylis } & 10.8 & 21.7 & 10.8 & 16.2 & 11.8 & 100 & 33.48 & 122.63 & $S$ & Mt Howick (MH) \\
\hline & 16.2 & 21.7 & 5.4 & 18.9 & 11.8 & 100 & & & & \\
\hline \multirow[t]{2}{*}{ Banksia praemorsa } & 11.2 & 15.5 & 4.3 & 13.4 & 19.9 & 100 & 35.12 & 117.90 & $S$ & Albany \\
\hline & 16.8 & 15.5 & 1.3 & 16.2 & 19.9 & 100 & & & & \\
\hline Banksia prionotes & 12.5 & 22.2 & 9.7 & 17.4 & 10.8 & 100 & 29.80 & 115.80 & $\mathrm{~N}$ & Carnamah (C) \\
\hline Banksia prionotes & 17.9 & 19.4 & 1.5 & 18.7 & 10.3 & 100 & 27.65 & 114.33 & $\mathrm{~N}$ & Kalbarri (K) \\
\hline Banksia pulchella & 11.3 & 18.9 & 7.5 & 15.1 & 11.6 & 100 & 33.86 & 123.49 & $S$ & Esperance \\
\hline Banksia quercifolia & 21.8 & 10.3 & 11.5 & 16.0 & 22.7 & 90 & 34.98 & 117.43 & $S$ & Denmark \\
\hline Banksia scabrella & 5.1 & 25.3 & 20.2 & 15.2 & 16.3 & 100 & 29.09 & 115.18 & $\mathrm{~N}^{*}$ & Geraldton \\
\hline Banksia sceptrum & 19.1 & 23.7 & 4.6 & 21.4 & 18.1 & 100 & 27.86 & 114.78 & $\mathrm{~N}$ & Kalbarri \\
\hline Banksia seminuda & 13.7 & 36.3 & 22.6 & 25.0 & 18.2 & 60 & 34.42 & 116.15 & $S$ & Manjimup \\
\hline Banksia sphaerocarpa \# & 10.5 & 17 & 6.5 & 13.8 & 16.0 & 100 & 33.09 & 118.18 & $\mathrm{~S}$ & Lake Grace \\
\hline Banksia solandri & 18.4 & 8.1 & 10.3 & 13.2 & 22.6 & 100 & 34.42 & 117.94 & $S^{*}$ & Stirling Range \\
\hline Banksia speciosa & 16.6 & 16.1 & 0.6 & 16.3 & 13.8 & 100 & 33.85 & 123.33 & $S$ & Esperance \\
\hline Banksia telmatiaea & 21.2 & 14.9 & 6.3 & 18.0 & 13.0 & 100 & 30.54 & 115.23 & $\mathrm{~N}$ & Jurien \\
\hline Banksia verticillata & 19.4 & 15.4 & 4.0 & 17.4 & 15.5 & 100 & 35.11 & 117.93 & $S^{*}$ & Albany \\
\hline Banksia victoriae & 12.0 & 23.2 & 11.2 & 17.6 & 9.0 & 100 & 27.62 & 114.40 & $\mathrm{~N}$ & Kalbarri \\
\hline Banksia violaceae & 19.0 & 13.5 & 5.4 & 16.2 & 15.8 & 100 & 33.09 & 118.18 & S & Munglinup (M) \\
\hline Banksia violaceae & 5.4 & 19 & 13.6 & 12.2 & 20.1 & 100 & 33.75 & 120.49 & $S$ & Lake Grace (LG) \\
\hline
\end{tabular}

$\mathrm{S}=$ southern; $\mathrm{N}=$ northern; $\mathrm{W}=$ widespread; ${ }^{*}$ species of conservation concern. 
that time point; and $N=$ total number of seeds germinated. The temperature values for each cell of the gradient plate (diurnal temperatures, average of day/ night temperatures, and amplitude of temperature range) were used as the independent variables to construct four alternative models. Model 1 used the day and night temperatures within each cell as independent variables; model 2 used mean temperature in each cell as the independent variable; model 3 used the amplitude of temperature fluctuation in each cell; and model 4 used a combination of mean and amplitude of temperature. To allow for possible non-linear responses to temperature, the squares of each temperature variable were included in each model. In all models a binary variable was included denoting the timing of light during the diurnal cycle (i.e. whether light coincided with the warm or cool part of the cycle) as one-half of the cells on the temperature-gradient plate had both day and night phases when temperature was higher (the latter being less meaningful, ecologically). Once the best-fitting of the four alternative models for MTG and germination were determined (based on the lowest deviance value), the optimal temperature conditions (day/night temperature cycle) for germination for each species was estimated.

Finally, using the best-fitting models described above, the projected responses of each species under current and forecast monthly average minimum and maximum temperature conditions for two greenhouse gas emission scenarios were estimated, thus providing a germination response for each month of the year. These temperatures were derived from climate projections from the HADGEM2-ES GCM that were downscaled and calibrated using WorldClim as the baseline 'current' climate (1950-2000). The two greenhouse gas scenarios were low (RCP 2.6) and high emission (RCP 8.5) for 2050 (average 2041-2060) and 2070 (average (20612080). Statistical analysis was conducted in GENSTAT 16th edition (VSN International, Hemel Hempstead, Herts, UK); contour plots showing germination on the bi-directional temperature gradient plate were created using Origin 9.1 (Origin Lab Corporation ${ }^{\circledR}$, Northampton, Massachusetts, USA).

\section{Results}

\section{Observed results}

Optimal temperature conditions for germination for each collection were identified by locating the grid cell or cells on the temperature gradient plate that delivered highest germination of seed in the shortest possible time (Table 1), the results thus acting as a finescale indicator of peak germination season for each species. Most species returned complete germination in at least one cell of the plate over the 6-week incubation period, with the exception of $B$. coccinea $(89 \%)$, B. seminuda $(60 \%)$, and B. quercifolia and B. brownii $(90 \%)$. The mean and amplitude of temperature that produced highest germination in the shortest possible time varied between species: mean temperatures ranged from $10.4^{\circ} \mathrm{C}$ (B. dryandroides) to $25^{\circ} \mathrm{C}$ (B. seminuda), with an overall mean of $16.2^{\circ} \mathrm{C}$; temperature amplitudes ranged from less than $1^{\circ} \mathrm{C}$ (temperatures virtually constant) to $22.6^{\circ} \mathrm{C}$ (large temperature oscillations). The estimates of the mean temperature for germination were related to latitude from where seeds were sourced $\left(r^{2}=0.4369\right.$, Fig. 2); however, the optimal temperature amplitude for germination had no relationship to latitude $\left(r^{2}=0.0491\right)$, as increasing temperature amplitudes resulted in both positive and negative germination performance and were thus meaningless in forecasting germination response. The mean time to complete germination (MTG) at the optimal temperature regime ranged from $8 \mathrm{~d}$ (B. leptophylla) to $26.7 \mathrm{~d}$ (B. coccinea), with a mean of $15.5 \mathrm{~d}$ across all collections (Table 1). Examples of contour plots describing germination over the range of temperatures on the gradient plate are presented in Fig. 3. The full complement of contour plots for all collections is accessible in supplementary Fig. S1.

\section{Model predictions}

The diurnal temperature cycle (model 1) or the combined effects of mean and amplitude of the diurnal cycle (model 4) provided the most accurate predictions for germination performance under current and future temperature conditions. The goodness of fit between the actual (TGP observed data) and the predicted germination responses as returned by the

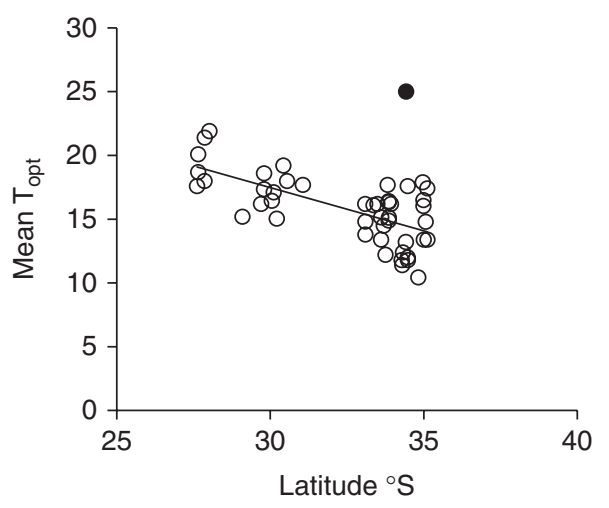

Figure 2. Relationship between latitude and mean optimal temperature (Topt) for germination in 41 species (47 collections) of Banksia from the South Western Australian Floristic Region $\left(r^{2}=0.4369\right)(P<0.0001)$. Note: one species was removed (B. seminuda, - ) as an outlier and was not included in the regression line. 

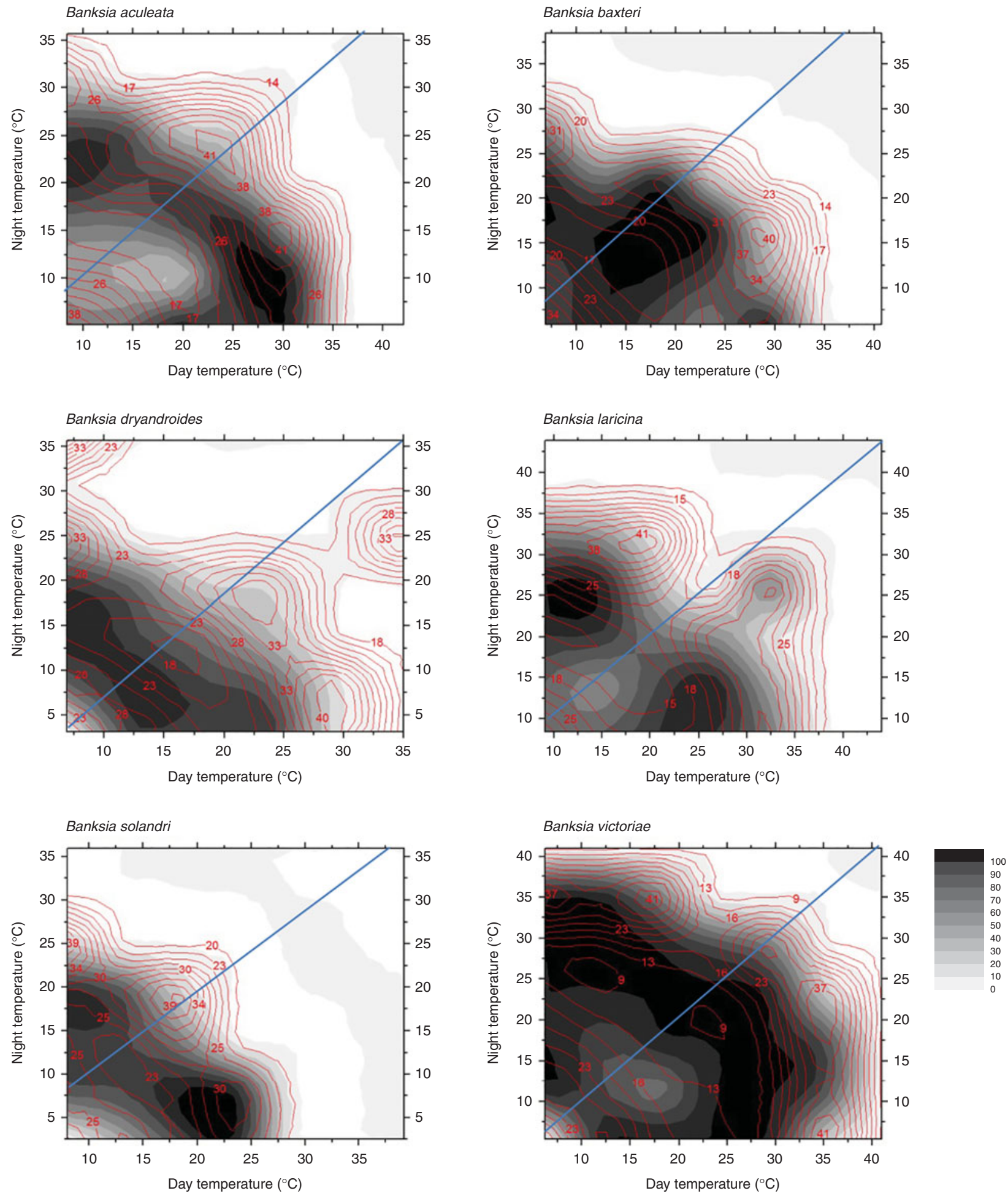

Figure 3. Six examples of contour plots for observed data for seeds of Banksia aculeata, B. baxteri, B. dryandroides, B. solandri and $B$. victoriae. Points of equal percentage germination are connected by germination isopleths. The gradation in colours from dark (black $=100 \%$ ) to light (white $=0 \%$ ) represent decreasing percentage germination. The contour lines within each plot represent mean time to germination at various levels of germination. Constant temperatures are presented on the diagonal line from the bottom-left corner of the diagrams (lowest temperature $c .5^{\circ} \mathrm{C}$ ) to the top-right corner (maximum temperature $c .40^{\circ} \mathrm{C}$ ). All points above and below the diagonal line represent alternating temperature regimes, with greatest amplitude at the top-left and bottom-right corners of each graph. The diagonal line from bottom left to top right corner of each plot signifies the divide between diurnal cycles that have light during the warmer day regime (bottom right section) and dark during the warmer day regime (top left section). 
model was tested for each species using the coefficient of determination. Germination responses to the temperature increases forecast for 2050 (RCP 2.6 and 8.5) and for 2070 (RCP 2.6) lay between the current (1950-2000) and predicted 2070 (RCP 8.5) response and only the latter comparisons are reported here. Across all collections, the $R^{2}$ was better at explaining variation in percentage germination $(84 \%)$ than in germination timing (65\%) (see supplementary Table S1); however, both were highly significant $(P>0.001)$. The discrepancy between observed and predicted values was low when taking into account the number of temperature samples (49 per species). Models 2 and 3 (mean of diurnal cycle and amplitude of diurnal cycle, respectively) proved less accurate as predictors of future germination, as determined by the deviance value in each model. Most species appear to have no specific light requirement during the warmer phase of the diurnal cycle, as high germination occurs both above and below the diagonal line; however, the models predicted that light during the warm phase of the thermal cycle was important for germination for nine of the southern species (B. baueri, baxteri, $B$. brownii, B. coccinea, B. media, B. meisneri, B. nutans, $B$. occidentalis and $B$. quercifolia) but only one of the northern species (B. benthamiana).

Overall, five distinct germination response curves were identified for the forecast conditions. The most common prediction for germination response (19 species; 20 collections) was for higher germination during the usually cooler winter months (Jun-Aug) compared to that predicted under current winter conditions (Fig. 4a). The greatest shift in percentage germination during the winter months was experienced by B. blechnifolia from the south of the SWAFR: under current temperature conditions the month of May delivers the highest germination potential $(100 \%)$, with winter temperatures during July producing lower germination $(67 \%)$. However, under future temperature conditions, germination is predicted to rise to $90 \%$ in that month. In the north, B. burdettii showed a similar pattern, where germination was currently optimal under conditions experienced in May and declined to $50 \%$ over the winter months; under future temperature conditions germination was predicted to increase to $74 \%$ in July. It can be seen, therefore, that these two species currently favour the warmer autumn temperature conditions for optimum germination, a period when moisture is usually available. A similar response was seen in other species (e.g. B. caleyi and $B$. benthamiana), but the winter increase in germination was predicted to be smaller. The pattern of germination timing was mixed: some species experienced more rapid and complete germination response in the winter months (e.g. B. attenuata: from $91 \%$ in $22 \mathrm{~d}$ under current conditions to $96 \%$ in $18 \mathrm{~d}$ under predicted conditions; B. sceptrum: $56 \%$ in $24 \mathrm{~d}$ compared to $71 \%$ in $19 \mathrm{~d})$. For some species (e.g. B. coccinea, B. quercifolia and B. lanata) there was virtually no change in MTG in conjunction with the increase in percentage germination in the winter months, but in most cases MTG increased exponentially under future thermal conditions either side of the traditionally cooler temperatures of May to October.

The second example of predicted germination responses to warmer temperatures was a narrowing of the germination window (for maximum germination) over the winter months (Fig. 4b). Some 15 species (17 collections) displayed this response. In most cases, MTG response to warmer temperatures was again mixed.

A third response was provided by species that showed relatively little decline in germination under the forecast warmer temperatures. This response was seen in two critically endangered species with restricted southern distributions (B. brownii and B. verticillata) as well as in five other commonly occurring species with larger geographic distributions (8 collections: see, for an example, Fig. 4c). Mean time to germination again varied, sometimes becoming higher during the critical winter months (e.g. B. grandis and B. leptophylla) and sometimes lower (e.g. B. media and $B$. pilostylis). Only one species (B. seminuda) displayed a reduction in mean time to germination while increasing percentage germination in all months under forecast conditions (Fig. 4d).

A single species (B. dryandroides) responded to the predicted warmer temperatures by an increase in germination rate but lower final germination across all months, suggesting that this species is most likely to decline under future climate scenarios (Fig. 4e).

Both different and similar germination responses occurred among populations of the species that were tested across multiple populations. Three collections of Banksia baueri (SRNP, EMB and TR) displayed two different germination responses when modelled against predicted future temperature conditions: seeds from EMB and SRNP populations currently have high winter germination, which does not appear to change under future forecast conditions (Fig. 5a, b). Population TR, at slightly lower latitude, currently has lower germination during the cooler winter months than either population SRNP or EMR, but under forecast future conditions germination will increase during the winter months (Fig. 5c). All three populations exhibit a narrowing of the germination window under future conditions. Other species that were represented by two collections from different localities (B. attenuata, B. pilostylis, B. prionotes and $B$. violaceae) did not appear to differ from each other in their responses in any notable way (data not shown), with the exception of B. prionotes (Fig. 6a, b). The more southern collection of this species exhibited a much narrower window for germination, with germination 

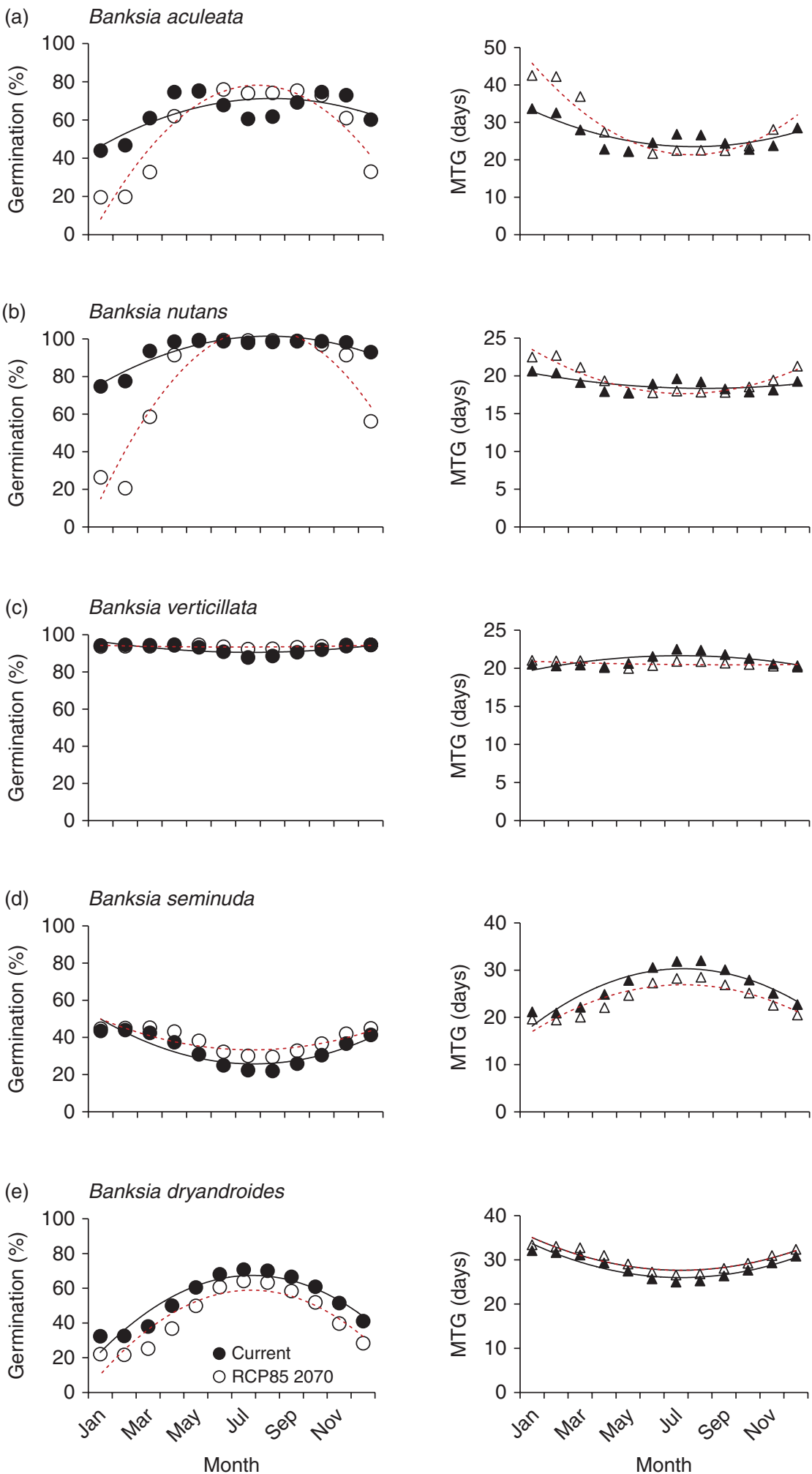

Figure 4. Five examples of species germination response to modelled current and predicted (RCP 8.5 for 2070) temperature conditions. Left panels: percentage germination; right panels: mean time to germination (MTG). • , Predicted current germination; $\bigcirc$, predicted future germination; $\boldsymbol{\Lambda}$, predicted current MTG; $\Delta$, predicted future MTG. (a) Maximum germination increases during winter months; (b) the window of opportunity for high germination narrows; (c) germination changes are minimal; (d) higher germination combined with lower mean time to germination; and (e) germination consistently lower all year. Solid lines represent the regression fit to current temperatures; dotted lines for predicted temperatures (RCP 8.5 for 2070). 

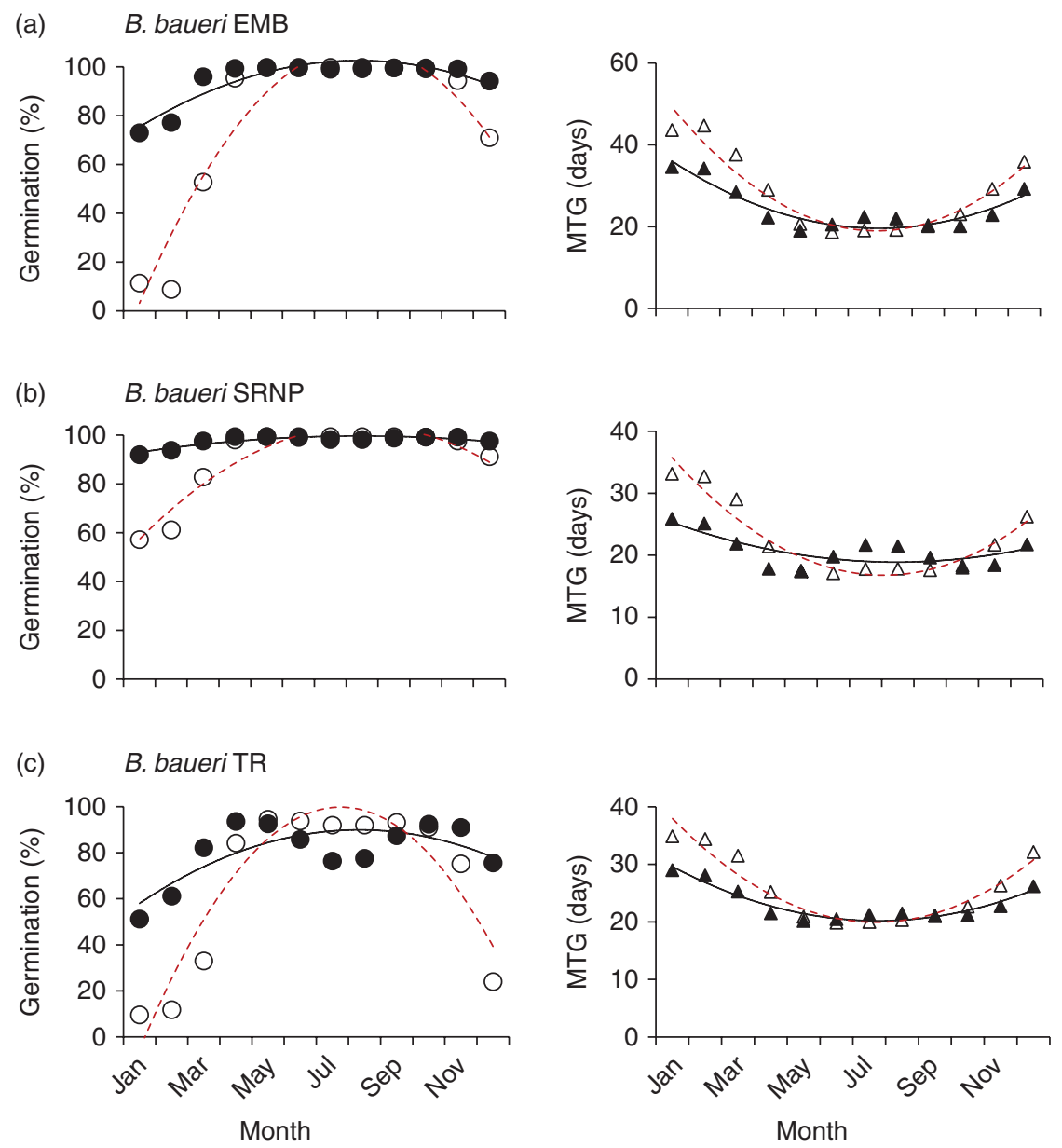

Figure 5. Modelled germination for three collections of Banksia baueri under current temperature conditions and predicted conditions using the high-emission greenhouse gas scenario (RCP 8.5) for 2070. Left panels: percentage germination; right panels: mean time to germination $(\mathrm{MTG})$. $\bullet$, Predicted current germination; $\bigcirc$, predicted future germination; $\boldsymbol{\Delta}$, predicted current MTG; $\Delta$, predicted future MTG.

declining steeply either side of this window. In contrast, the northern population $(>300 \mathrm{~km}$ from the southern population) demonstrated a much wider germination window during the autumn-winter months.

\section{Discussion}

\section{Observed and modelled germination response}

Many of the species investigated displayed a broad thermal sensitivity for germination under a range of temperature conditions, greater than expected based on their current distributions alone, and for those species represented by multiple seed lots, there was evidence of both among-population differences and similarities. The models predicted that temperatures for germination for most species are currently optimal in late autumn (May). In the SWAFR this is traditionally the timing of the 'break' in weather, when autumn rainfall commences and the soils are still relatively warm.

The first hypothesis, that increasing temperatures relevant to the climate scenarios would alter germination traits, proved correct, with timing of maximum germination for many species predicted to advance from late autumn into early winter, as the onset of germination was delayed by temperatures above the current temperatures generating maximum germination. Shifts in timing of emergence under global warming scenarios have been reported previously in northern hemisphere alpine and sub-arctic species (a shift from spring- to autumn-dominated emergence) (Milbau et al., 2009; Mondoni et al., 2012, 2015). In seasonally dry ecosystems like the SWAFR, germination timing is critical when moisture is a limiting factor, and there can be considerable fitness losses for organisms that fail to time behaviours optimally (McNamara et al., 2011). Delayed germination may result in reduced fitness in a competitive 

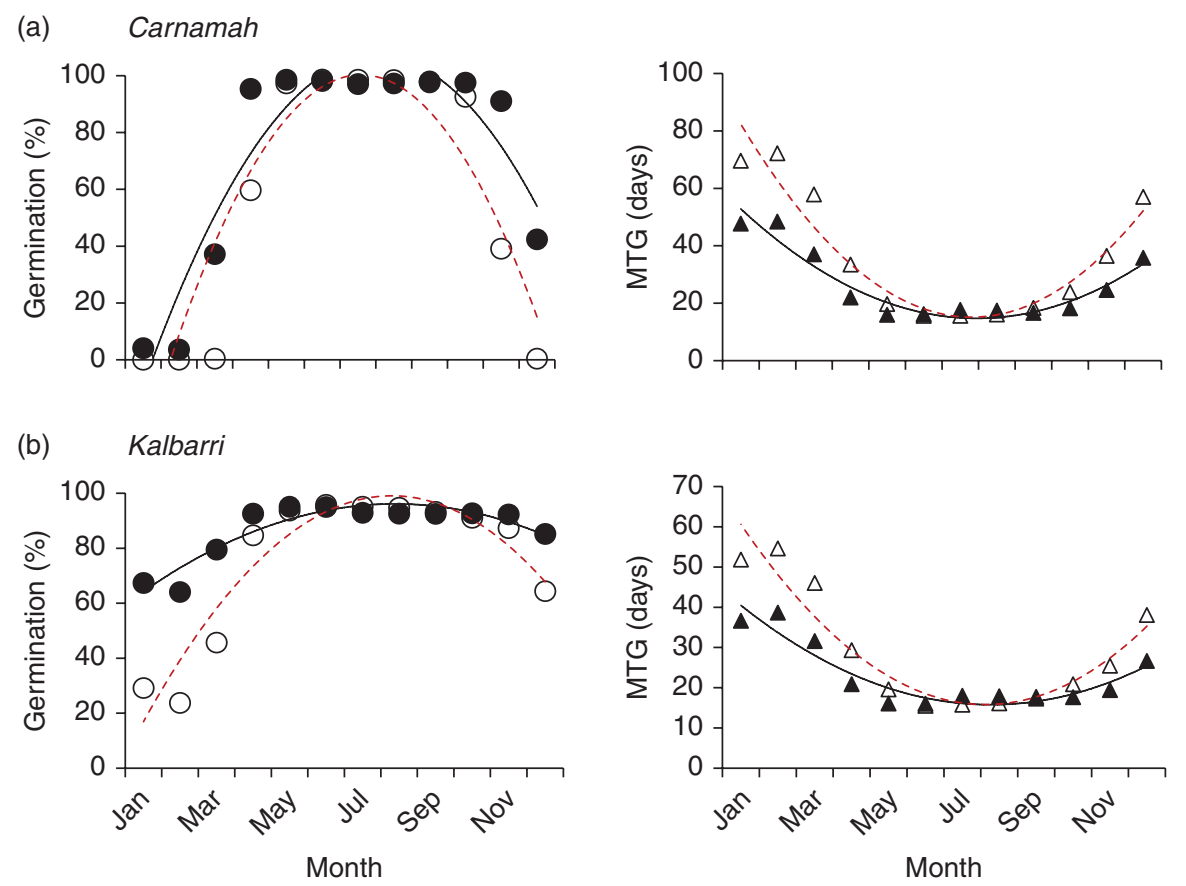

Figure 6. Differences in modelled germination of two collections of Banksia prionotes under current temperature conditions and predicted conditions using high-emission greenhouse gas scenario (RCP 8.5) for 2070. Left panels: percentage germination; right panels: mean time to germination $(\mathrm{MTG})$. $\bullet$, Predicted current germination; $\bigcirc$, predicted future germination; $\boldsymbol{\Delta}$, predicted current MTG; $\Delta$, predicted future MTG.

environment, with the possibility of invasion by other quicker growing species more adept at coping with new conditions. However, slower germination may also be considered a risk-spreading strategy (see Zammit and Westoby, 1987) as not all seeds commit to a single rainfall event. Those species that were found to increase the speed (and total germination) response under future scenarios may potentially reduce their ability to cope with increasingly variable rainfall, even during the wet season.

The models used in this study further predict that rising temperatures associated with anthropogenic climate warming are unlikely to adversely affect levels of seed germination in wild populations of many obligate-seeding Banksia species per se. For some species there may be a benefit from variability in environmental conditions, as it may lead to more frequent conditions for recruitment (i.e. increased germination during the cooler months of the year relative to current expectations). Actual declines in germination under the region's forecast temperature increases across all months of the year are expected in only one species (B. dryandroides). This species has no close relations with other species in the Banksia phylogeny and lies in the monophyletic series Dryandroideae (Mast and Givnish, 2002). The impact of climate change on the geographic distribution of $B$. dryandroides has been modelled by Fitzpatrick et al. (2008) and Yates et al. (2010), and both studies predicted a severe reduction in range size for this species based on a reduction in rainfall forecast for the region. $B$. dryandroides is a relatively short-range endemic with a predominantly coastal, east-west geographic distribution of less than $170 \mathrm{~km}$, but it is not yet considered of conservation concern, despite populations being generally small and fragmented (Sarah Barrett, pers. comm., May 2015, Department of Parks and Wildlife). A change in the number of seeds that germinate and/or the timing of that germination can result in a decline in seedling abundance with the potential for population and species extirpation, leading to a change in vegetation community dynamics. In the light of these current results, a closer look at the conservation status of this species may be required in the future.

The second hypothesis, that species with more restricted distributions would be disproportionately affected by the temperature changes forecast for the region, was not fully supported. Southern- and northern-distributed species varied little in their thermal sensitivity for germination and, contrary to expectations and previous research (e.g. see Luna et al., 2012), species with more restricted distributions (i.e. the species of conservation concern) were not considered more thermally sensitive or disproportionately affected by forecast temperature change. For two geographically restricted conservation-listed species ( $B$. brownii and $B$. verticillata), the models predict that germination will alter little under the forecast warmer conditions, and neither the timing nor the percentage of germination is predicted to change. 
In isolation, the mean incubation temperature was shown to be inadequate for predicting future germination response, and temperature fluctuations (either as diurnal temperatures, or the amplitude of temperature fluctuations coupled with the mean) appear to be more important for predicting current and future germination performance. Changes in the means and amplitudes can result in both positive and negative germination performance, as the typical thermal performance curve is non-linear and performance can vary relative to the value predicted by a mean temperature (Vasseur et al., 2014). The models were designed to incorporate variability in climate by considering mean monthly minimum and maximum temperatures forecast for each specific seed source site, to provide a more 'realistic' prediction of germination response to changing temperature conditions. However, estimates from WorldClim are for air temperatures and do not reflect the temperatures that a seed experiences at the soil surface, which can be considerably higher (Ooi, 2012). In the absence of soil-surface temperature data for individual sites, modelled air temperatures from WorldClim have been used. These data, though, are likely to be an underestimation of soil-surface temperatures, in particular during the summer months. In addition, the bare soils of a post-fire environment would absorb more heat than those with covering vegetation, and as most species investigated in this study require fire for serotinous seed release and dispersal, this may help to explain why seeds can germinate over a wide range of temperatures, some quite high.

These predictions are also made without considering the key limiting factor of moisture. Mediterraneantype ecosystems like the SWAFR typically experience winter-wet, summer-dry climates, and the germination of many plant species coincides with the cooler moist conditions of autumn-winter. The observed pattern of Banksia species richness is closely linked to precipitation gradients (Lamont and Connell, 1996) and without moisture there will be no recruitment opportunities for non-sprouting species regardless of temperature. Across the seed source sites, the bioclimatic models predict a reduction in mean annual precipitation of between $14 \%$ and $29 \%$ (RCP 2.6 for 2050 and RCP 8.5 for 2070, respectively), which will result in further declines in net accumulated rainfall available to seeds and newly emerged seedlings of between 25 and 55\%. The predicted delays in germination in conjunction with these forecast declines in rainfall will place seedlings of most species closer to the forecast drier summer dry and thus more vulnerable to desiccation. Even if a species is capable of continuing to occupy a site, a changing climate could result in the organism being further from its physiological optimum and therefore closer to the edge of its range, and thus at risk of being outcompeted.
Further research is urgently required to understand the interaction of temperature and moisture stress on seed germination in this genus.

\section{Population variation and multiple drivers of environmental change}

Species' environmental limits are not necessarily stable, and the presence of intra-specific variation can lend a dynamic nature to the tolerance limits of a species, depending on the interaction of gene flow, natural selection and demography (Davis and Shaw, 2001). Consequently, inferring threat on the basis of results from one population should be viewed with caution, given the variation in germination patterns already observed along environmental gradients in this and other studies (e.g. Hernández-Verdugo et al., 2001; Cochrane et al., 2014a, b, 2015). Identifying spatial patterns in germination thresholds can help us to understand species' range distributions, in particular under changing climates (Qiu et al., 2010), with failure to consider individual population responses potentially over- or underestimating the plasticity and capacity for adaptation to new conditions (Albert et al., 2010, Beierkuhnlein et al., 2011).

The quantification of thermal sensitivity for a single reproductive trait also needs to be considered in the context of multiple environmental drivers, species interactions (see Berg et al., 2010) and the dynamics of colonization. Adult mortality, coupled with declining or delayed seedling recruitment, has the ability to change species dynamics with implications for community structure and function. Changes in fire regime associated with climate change include more frequent and more intense fires (Flannigan et al., 2009), and these changes have the potential to lead to loss of serotinous species such as Banksia. Too frequent fire may constrain maturation of the aerial seed bank, while a lengthy disturbance interval may exceed the life span of individuals. Alternatively, a favourable fire regime change may stimulate population growth if the new regime better matches the life history and reproductive timing of those species (Buma et al., 2013). Species may persist under sub-optimal climatic conditions, or a narrowing of the germination window, but high mortality of seedlings post-fire due to reduced rainfall may gradually erode population size, in conjunction with pressure from other stressors. Post-release granivory and herbivory, as well as unsuitable germination conditions, mean that few viable seeds become seedlings after fire (Lamont and Groom, 1998; Lamont et al., 2007). Loss of plants through disease, in particular Phytophthora cinnamomi, compounds management and conservation challenges in the SWAFR (Shearer et al., 2004, 2007). The interaction of disease and a changing climate is predicted 
to exacerbate the risk of native plant extinction (Chakraborty et al., 1998; Sutherst, 2000).

\section{Conclusions}

The dynamics of regeneration by seeds under changing climates is a pressing global issue for plants and is in need of further research. Details on seed performance under a range of environmental conditions will assist in understanding how climate change may affect plant regeneration. Linking observed biological data with historical and forecast diurnal seasonal temperature data from climate modelling can help set priorities for the development of more effective management strategies that may reduce the chances of climatedriven extinction. In the light of these results, future research could be aimed at screening species for their environmental thresholds, in conjunction with monitoring the effects of a warming and drying climate on recruitment in the species most temperature-limited for germination, or, in the case of seasonally dry ecosystems, where drastic reductions in rainfall are forecast. Despite the high level of uncertainty in climate projections, it is vital that we incorporate expected future climates into recovery planning and restoration practice, as the usefulness of historical ecosystem conditions is questioned (Harris et al., 2006).

\section{Supplementary material}

To view supplementary material for this article, please visit http://dx.doi.org/10.1017/S0960258515000355.

\section{Acknowledgements}

The author thanks Susanne Schreck for technical assistance with seed collection and germination, Dr Mathew Williams for statistical advice and Dr Adrienne Nicotra for comments on a previous draft. Three anonymous reviewers are acknowledged for their comments, which greatly improved the paper.

\section{Financial support}

This research was supported by a Natural Heritage Trust grant from the Australian Government through the South Coast Natural Resource Management Inc. (Project 04SC1-13h) and the Millennium Seed Bank Project, Royal Botanic Gardens Kew, UK.

\section{Conflicts of interest}

None.

\section{References}

Albert, C.H., Thuiller, W., Yoccoz, N.G., Soudant, A., Boucher, F., Saccone, P. and Lavorel, S. (2010) Intraspecific functional variability: extent, structure and sources of variation. Journal of Ecology 98, 604-613.

Bates, B.C., Hope, P., Ryan, B., Smith, I. and Charles, S. (2008) Key findings from the Indian Ocean Climate Initiative and their impact on policy development in Australia. Climatic Change 89, 339-354.

Bates, B., Frederiksen, C. and Wormworth, J. (2012) Western Australia's weather and climate: a synthesis of Indian Ocean Climate Initiative Stage 3 Research. Indian Ocean Climate Initiative, CSIRO and BoM, Australia.

Beierkuhnlein, C., Thiel, D., Jentsch, A., Willner, E. and Kreyling, J. (2011) Ecotypes of European grass species respond differently to warming and extreme drought. Journal of Ecology 99, 703-713.

Berg, M.P., Kiers, E.T., Driessen, G., van der Heijden, M., Kooi, B.W., Kuenen, F., Liefting, M., Verhoef, H.A. and Ellers, J. (2010) Adapt or disperse: understanding species persistence in a changing world. Global Change Biology 16, 587-598.

Bond, W.J. and Midgley, J.J. (2001) Ecology of sprouting in woody plants: the persistence niche. Trends in Ecology and Evolution 16, 45-51.

Bradstock, R.A. (1991) The role of fire in establishment of seedlings of serotinous species from the Sydney region. Australian Journal of Botany 39, 347-356.

Broadhurst, L.M., North, T. and Young, A.G. (2006) Should we be more critical of remnant seed sources being used for revegetation? Ecological Management and Restoration 7, 211-217.

Buma, B., Brown, C.D., Donato, D.C., Fontaine, J.B. and Johnstone, J.F. (2013) The impacts of changing disturbance regimes on serotinous plant populations and communities. BioScience 63, 866-876.

Chakraborty, S., Murray, G.M., Magarey, P.A., Yonow, T., O'Brien, R.G., Croft, B.J., Barbetti, M.J., Sivasithamparam, K., Old, K.M., Dudzinski, M.J., Sutherst, R.W., Penrose, L.J., Archer, C. and Emmett, R.W. (1998) Potential impact of climate change on plant diseases of economic significance to Australia. Australasian Plant Pathology 27, 15-35.

Cochrane, A., Daws, M.I. and Hay, F.R. (2011) Seed-based approach for identifying flora at risk from climate warming. Austral Ecology 36, 923-935.

Cochrane, A., Hoyle, G.L., Yates, C.J., Wood, J. and Nicotra, A.B. (2014a) Climate warming delays and decreases seedling emergence in a Mediterranean ecosystem. Oikos 124, 150-160.

Cochrane, A., Hoyle, G.L., Yates, C.J., Wood, J. and Nicotra, A.B. (2014b) Predicting the impact of increasing temperatures on seed germination among populations of Western Australian Banksia (Proteaceae). Seed Science Research 24, 195-205.

Cochrane, A., Yates, C.J., Hoyle, G.L. and Nicotra, A.B. (2015) Will among-population variation in seed traits improve the chance of species persistence under climate change? Global Ecology and Biogeography 24, 12-24.

Cowling, R.M. and Lamont, B.B. (1985) Variation in serotiny of three Banksia species along a climatic gradient. Australian Journal of Ecology 10, 345-350. 
Davis, M.B. and Shaw, R.G. (2001) Range shifts and adaptive responses to Quaternary climate change. Science 292, 673-679.

Fernández-Pascual, E., Seal, C.E. and Pritchard, H.W. (2015) Simulating the germination response to diurnally alternating temperatures under climate change scenarios: comparative studies on Carex diandra seeds. Annals of Botany 115, 201-209.

Fitzpatrick, M.C., Gove, A.D., Sanders, N.J. and Dunn, R.R. (2008) Climate change, plant migration, and range collapse in a global biodiversity hotspot: the Banksia (Proteaceae) of Western Australia. Global Change Biology 14, 1337-1352.

Flannigan, M.D., Krawchuk, M.A., de Groot, W.J., Wotton, B.M. and Gowman, L.M. (2009) Implications of changing climate for global wildland fire. International Journal of Wildland Fire 18, 483-507.

George, A.S. (1999) Banksia. pp. 175-251 in Wilson, A. (Ed.) Flora of Australia. Volume 17B: Proteaceae 3: Hakea to Dryandra. Collingwood, Victoria, CSIRO Publishing/ Australian Biological Resources Study.

Gworek, J.R., Vander Wall, S.B. and Brussard, P.F. (2006) Changes in biotic interactions and climate determine recruitment of Jeffrey pine along an elevation gradient. Forest Ecology and Management 239, 57-68.

Harper, J.L. (1977) Population biology of plants. London, Academic Press.

Harris, J.A., Hobbs, R.J., Higgs, E. and Aronson, J. (2006) Ecological restoration and global climate change. Restoration Ecology 14, 170-176.

Hernández-Verdugo, S., Oyama, K. and Vázquez-Yanes, C. (2001) Differentiation in seed germination among populations of Capsicum annuum along a latitudinal gradient in Mexico. Plant Ecology 155, 245-257.

Hijmans, R.J., Cameron, S.E., Parra, J.L., Jones, P.G. and Jarvis, A. (2005) Very high resolution interpolated climate surfaces for global land areas. International Journal of Climatology 25, 1965-1978.

Hopper, S.D. and Gioia, P. (2004) The SouthWest Australian Floristic Region: evolution and conservation of a global hot spot of biodiversity. Annual Review of Ecology, Evolution, and Systematics 35, 623-650.

Hovenden, M.J., Wills, K.E., Chaplin, R.E., Vander Schar, J.K., Williams, A.L., Osanai, Y. and Newton, P.C.D. (2008) Warming and elevated $\mathrm{CO}_{2}$ affect the relationship between seed mass, germinability and seedling growth in Austrodanthonia caespitosa, a dominant Australian grass. Global Change Biology 14, 1633-1641.

Hughes, L., Cawsey, E.M. and Westoby, M. (1996) Climatic range sizes of Eucalyptus species in relation to future climate change. Global Ecology and Biogeography Letters 5, 23-29.

IPPC (2013) Climate Change 2013: The physical science basis. Contribution of Working Group I to the Fifth Assessment Report of the Intergovernmental Panel on Climate Change. Cambridge, UK, Cambridge University Press.

Jones, C.D., Hughes, J.K., Bellouin, N., Hardiman, S.C., Jones, G.S., Knight, J., Liddicoat, S., O'Connor, F.M., Andres, R.J., Bell, C., Boo, K.O., Bozzo, A., Butchart, N., Cadule, P., Corbin, K.D., Doutriaux-Boucher, M., Friedlingstein, P., Gornall, J., Gray, L., Halloran, P.R., Hurtt, G., Ingram, W.J., Lamarque, J.F., Law, R.M., Meinshausen, M., Osprey, S., Palin, E.J., Parsons Chini, L., Raddatz, T., Sanderson, M.G., Sellar, A.A., Schurer, A.,
Valdes, P., Wood, N., Woodward, S., Yoshioka, M. and Zerroukat, M. (2011) The HadGEM2-ES implementation of CMIP5 centennial simulations. Geoscientific Model Development 4, 543-570.

Lamont, B. and Connell, S.W. (1996) Biogeography of Banksia in southwestern Australia. Journal of Biogeography 23, 295-309.

Lamont, B. and Markey, A. (1995) Biogeography of firekilled and resprouting Banksia species in South-Western Australia. Australian Journal of Botany 43, 283-303.

Lamont, B., Enright, N., Witkowski, E. and Groeneveld, J. (2007) Conservation biology of banksias: insights from natural history to simulation modelling. Australian Journal of Botany 55, 280-292.

Lamont, B.B. and Groom, P.K. (1998) Seed and seedling biology of the woody-fruited Proteaceae. Australian Journal of Botany 46, 387-406.

Lamont, B.B., de Maitre, D.C., Cowling, R.M. and Enright, N.J. (1991) Canopy seed storage in woody plants. The Botanical Review 57, 277-317.

Lloret, F., Peñuelas, J. and Estiarte, M. (2004) Experimental evidence of reduced diversity of seedlings due to climate modification in a Mediterranean-type community. Global Change Biology 10, 248-258.

Luna, B., Pérez, B., Torres, I. and Moreno, J. (2012) Effects of incubation temperature on seed germination of Mediterranean plants with different geographical distribution ranges. Folia Geobotanica 47, 17-27.

Malcolm, J., Liu, C., Neilson, R., Hansen, L. and Hannah, L. (2006) Global warming and extinctions of endemic species from Biodiversity Hotspots. Conservation Biology 20, 538-548.

Mast, A.R. and Givnish, T.J. (2002) Historical biogeography and the origin of stomatal distributions in Banksia and Dryandra (Proteaceae) based on their cpDNA phylogeny. American Journal of Botany 89, 1311-1323.

Mast, A.R. and Thiele, K. (2007) The transfer of Dryandra R.Br. to Banksia L.f. (Proteaceae). Australian Systematic Botany 20, 63-71.

McCarthy, J.P. (2001) Ecological consequences of recent climate change. Conservation Biology 15, 320-331.

McNamara, J.M., Barta, Z., Klaassen, M. and Bauer, S. (2011) Cues and the optimal timing of activities under environmental changes. Ecology Letters 14, 1183-1190.

Milbau, A., Graae, B.J., Shevtsova, A. and Nijs, I. (2009) Effects of a warmer climate on seed germination in the subarctic. Annals of Botany 104, 287-296.

Mondoni, A., Rossi, G., Orsenigo, S. and Probert, R.J. (2012) Climate warming could shift the timing of seed germination in alpine plants. Annals of Botany 110, 155-164.

Mondoni, A., Pedrini, S., Bernareggi, G., Rossi, G., Abeli, T., Probert, R.J., Ghitti, M., Bonomi, C. and Orsenigo, S. (2015) Climate warming could increase recruitment success in glacier foreland plants. Annals of Botany 116, 907-916.

Nicotra, A.B., Atkin, O.K., Bonser, S.P., Davidson, A.M., Finnegan, E.J., Mathesius, U., Poot, P., Purugganan, M.D., Richards, C.L., Valladares, F. and van Kleunen, M. (2010) Plant phenotypic plasticity in a changing climate. Trends in Plant Science 15, 684-692.

Ooi, M.K.J. (2012) Seed bank persistence and climate change. Seed Science Research 22, S53-S60.

Ooi, M.K.J., Auld, T.D. and Denham, A.J. (2009) Climate change and bet-hedging: interactions between increased 
soil temperatures and seed bank persistence. Global Change Biology 15, 2375-2386.

Parmesan, C. and Yohe, G. (2003) A globally coherent fingerprint of climate change impacts across natural systems. Nature 421, 37-42.

Pearson, R.G. and Dawson, T.P. (2003) Predicting the impacts of climate change on the distribution of species: are bioclimatic envelope models useful? Global Ecology and Biogeography 12, 361-371.

Pouliquen-Young, O. and Newman, P. (2000) The implications of climate change for landbased nature conservation strategies. Canberra and Perth, Australian Greenhouse Office, Environment Australia and Murdoch University.

Probert, R.J. (2000) The role of temperature in the regulation of seed dormancy and germination. pp. 261-292 in Fenner, M. (Ed.) Seeds. The ecology of regeneration in plant communities. Wallingford, UK, CABI International.

Qiu, J., Bai, Y., Fu, Y.-B. and Wilmshurst, J.F. (2010) Spatial variation in temperature thresholds during seed germination of remnant Festuca hallii populations across the Canadian prairie. Environmental and Experimental Botany 67, 479-486.

Shearer, B.L., Crane, C.E. and Cochrane, A. (2004) Quantification of the susceptibility of the native flora of the South-West Botanical Province, Western Australia, to Phytophthora cinnamomi. Australian Journal of Botany 52, 435-443.
Shearer, B.L., Crane, C.E., Barrett, S. and Cochrane, A. (2007) Phytophthora cinnamomi invasion, a major threatening process to conservation of flora diversity in the South-west Botanical Province of Western Australia. Australian Journal of Botany 55, 225-238.

Silvertown, J. and Charlesworth, D. (2001) Introduction to plant population biology. Melbourne, Blackwell Science.

Sutherst, R.W. (2000) Climate change and invasive species: a conceptual framework. pp. 211-240 in Mooney, H.A.; Hobbs, R.J. (Eds) Invasive species in a changing world. Washington, Island Press.

Vasseur, D.A., DeLong, J.P., Gilbert, B., Greig, H.S., Harley, C.D.G., McCann, K.S., Savage, V., Tunney, T.D. and O'Connor, M.I. (2014) Increased temperature variation poses a greater risk to species than climate warming. Proceedings of the Royal Society B: Biological Sciences 281, doi:10.1098/rspb.2013.2612.

Whelan, R.J. (1995) The ecology of fire. Cambridge, Cambridge University Press.

Yates, C.J., McNeill, A., Elith, J. and Midgley, G.F. (2010) Assessing the impacts of climate change and land transformation on Banksia in the South West Australian Floristic Region. Diversity and Distributions 16, 187-201.

Zammit, C. and Westoby, M. (1987) Seedling recruitment strategies in obligate-seeding and resprouting Banksia shrubs. Ecology 68, 1984-1992. 